\title{
Recreating a Vibrant City Center in Response Urban Environments by Using AHP Model (Case Study: Qazvin City Historical Context in Iran)
}

\author{
MohammadReza Sadeghi Moghadam ${ }^{1, *}$, Negin Mousavi ${ }^{1}$, Gelare Solgi ${ }^{1}$, Salameh Azimi ${ }^{2}$ \\ ${ }^{1}$ Department of urban planning, Qazvin Branch, Islamic Azad University, Qazvin, Iran \\ ${ }^{2}$ Department of Industrial Engineering, Qazvin Branch, Islamic Azad University, Qazvin. Iran \\ *Corresponding Author: m.sadeghi62@gmail.com
}

Copyright (C) 2014 Horizon Research Publishing All rights reserved.

\begin{abstract}
In this age of transition from decades of turmoil and instability in urban areas, urban centers validate their prestige and importance as a commercial, cultural and recreational center. Urban centers as the housing and shelter for millions of people and visitors will facilitate and improve human interaction. Since the city is very complex, existence and attendance of cycles of declining and wane, reform and reconstruction are obvious. At the best form, appearance of a city will be realized from its center \& heart. Recently, in western countries, having vibrant and dynamic urban centers has caught the attention of many scholars. Actually creating an environment where social interaction is high and gives people a sense of vitality. On the other hand, to include such dynamism in context of an urban center, it needs adequate respondents. Therefore, in this paper, at firs the criteria for responsive environments, characters of a vibrant city center and the main \& common features between them is introduced, using the analytic hierarchy process (AHP), criteria are weighted and prioritized. The results show that, sustaining the above criteria and codifying proposed policies and strategies, helps to recreate the historic core of Qazvin city.
\end{abstract}

Keywords Vibrant city center, Responsive environments, Socialization, AHP, Qazvin

\section{Introduction}

In Since the beginning of modern civilization, character of cities was distinguished by difference between private and public areas. The all times, it can be said that Greece rings were the best-known public spaces, public squares where the town meetings, public gatherings and places for ceremonies $\&$ feasts were considered, indeed, playing role as an integrated platform for social life in the city. In the middle ages, public spaces were still a main set to reveal public life.
A few centuries later, during the industrial revolution, urban regions growth developed implementation of urban planning in practice, as cities grew by developing social networks [1].

Urban space is not just a physical concept, but also contains citizen interactions and civic engagements. It means that public spaces bring an imagination for city fabric where is a place of establishing urban activities or an incidence of social interactions [2].

In the new centuries, sustainable development, vitality, and competitiveness, are some of the terms that direct planning and urban development. As a result, city centers are faced with many challenges simultaneously. Urban growth, demographic changes, and efforts to improve the quality of life, all of these areas are contiguous. In fact, high population density and citizens living conditions determines success or failure of city. So studying the quality of urban life is one of the most effective ways to measure the urban competitiveness. Also, people fleeing from rural areas to growing urban centers for improving appropriate living conditions is needed for maintaining this development on the right track [1].

Successive public places are characterized by people's attendance, in this way characters of such spaces are corroborated inly. Basically the common spaces are to be used when necessary. People should take advantage of these environments while they can choose other spaces for use. Such spaces should be full of crowd and dynamic. The solution is that people gather what they are interested, around and inside themselves [3].

A dynamic environment can be supposed as a place where human presence is clearly seen and public space as a context of social interactions, have enough attraction for the selection of the people. Such space has standard criteria for permeability, sense of place, flexibility, visual proportions, organizing structure and etc. that during this research, using the opinions of planning and designing experts and applying analytical process model offers appropriate solutions for recreating of these features at environment (the historic core of Qazvin city). 


\section{Theoretical Foundations}

\subsection{Definition of Socialization}

World "Jan Gehl" in definition of urban public spaces, emphasizes on its invitation more than any other characteristic of it, and believes that attractiveness of a city depends on the masses of people who gather in the public spaces and spend their good times at these places; according to him, inviting urban space, is a space where we can meet face to face with our fellow citizens and directly gain experiences with our awareness. John Lang commemorates social spaces as "welcoming places" and believes that such spaces are environments that can improve the human experience, have human scale, be context of various behaviors and activities and be able to accept people's desired behavior [2].

\subsection{Definition of the Vitality and Viability}

For the concept of vitality, there are diversity equivalents in the West, which can be noted as Liveliness, livability, Viability, Vitality, that all of their meanings except Vitality are so close to livability and life capability. In Robert Cowan urban dictionary, vitality and livability have come together and mean: vitality and viability [4]. Vibrancy is a raw power and vigor of city that needs to be focused and directed toward to achieve life capability [5]. In fact, the vibrancy is the bustle of a city center in variable locations and different time zones. And viability is about the center's ability to attract investment in the environment [6].

\subsection{Vibrant Urban Space}

According to the above definitions a "vibrant urban area" is an area of the city where a significant number of individuals (with different age and sex) in a wide range of time during day, are doing themselves or social activities [7].

Urban centers play an important role in the economic health of a town or city. Vitality of city centers booms economic activity and business in the region and finally attracts tourists to the area. In addition, the city center contains people's imagination of environment which is a valuable legacy for society. It is aesthetically pleasing urban center should be full of action, especially the pedestrian activity. Conveyance positive and attractive image of the community also helps to attract visitors to the core of city center. Thus, creating vibrant city center must be an important goal for community leaders [8]. Also Cyril B. Paumier ${ }^{1}$ in his book, named Creation a vibrant city center, has introduced four components to improve the efficiency of urban space, which are: 1-accessibility 2- land use diversity 3-concentration and density or compactness of land uses 4-organizer structure, Which briefly are described on the below.

Following this thinking and efforts to creating an environment with good quality for presence and social life of humans in the context, Bentley defines the responsive environment as: the belief that man-made places should enhance opportunities and provide a democratic environment, through the exquisite of people's available options. We call these places: responsive places.

In the late 1970s and early 1980s, a group at Oxford Polytechnic formulated an approach to the design of urban environment, named responsive environments, published as a guideline for urban designers. In this approach, the need for more democratic and richer environments that maximize the available choices consumers was emphasized. They believed that place designing would influence the possibility of people's choice, on the other meaning where they could and could not go - the existing consumptions range - possibility of understanding of existing facilities-possibility of usage of specific location for varied purposes - that a full detailed appearance makes them aware of the available options or not - their preferred sensory experience - how much they can stamp their personality on environment. This approach concentrated on seven important key components in creating responsive sites: permeability, variety, legibility, robustness, visual proportions, richness and personality [3].

\subsection{Economic Vitality}

Economic vitality has been examined in some important cities such as Waterloo and Concord [9, 10].

The City of Waterloo's economic vitality is a key pillar of success. Building, learning, living, playing and doing business in Waterloo are depends on a number of internal and external factors that require ongoing attention and action [9].

The Economic Vitality Strategy sets the vision, goals, and priorities for all City efforts related to economic development. The Strategy is usually updated every five years, in coordination with the City's General Plan, Redevelopment Plan, and other policy documents [10].

Several new industries are becoming increasingly important to a vibrant city's economy and have the potential to become major drivers in employment. These industries include:

Health Care, Financial Services, Retail, Engineering, Green/Clean-Tech/Energy, Applied Sciences, Life Sciences / Biotechnology, Professional \& Business Services. These emerging industries may have special needs with respect to infrastructure, workforce development, Zoning and General Plan issues, and business services. As importance of economic vitality, for creating a vibrant city, it's so necessary to emphasize.

\section{Defining Criteria for Vibrancy and Responsibility of Urban Environment}

With regard to urban designing as an important and basic field of study and research and identifying environmental qualities from the perspective of experts, the following table has compiled, which briefly describes the quality of responsive environment and city center vitality. 
Table 1. Definition of the components

\begin{tabular}{|c|c|c|}
\hline row & environmental qualities & Definition \\
\hline 1 & Accessibility & $\begin{array}{l}\text { Urban centers were considered as a center of regional transportation networks. Their accessibility results } \\
\text { in possibility of growth of production and business activities. }\end{array}$ \\
\hline 2 & Land use diversity & $\begin{array}{l}\text { Town centers are considered as places to provide facilities for residents, establishment of government } \\
\text { offices, courts, schools and cultural institutions. The diversity of land is more conducive to the presence } \\
\text { of diverse people and activities. }\end{array}$ \\
\hline 3 & $\begin{array}{l}\text { Concentration \& density or } \\
\text { land use jam }\end{array}$ & $\begin{array}{l}\text { Because land values are relatively high in urban centers, to maximize the occupancy levels is important } \\
\text { and this results in high jam and density. }\end{array}$ \\
\hline 4 & Organizer structure & Organized bound is more understandable and the possibility of construction and development is high. \\
\hline 5 & Permeability & $\begin{array}{l}\text { Accessibility to a location increases the choice of people. In fact, rate of permeability strengthen the } \\
\text { response of environment. A public space should be visually permeable not only to those who are familiar } \\
\text { to environment but also to absorb everybody. }\end{array}$ \\
\hline 6 & Diversity & $\begin{array}{l}\text { Diversity in both, land use and varied kind of buildings with different forms is considered, and is absorbs } \\
\text { different people in different times with different economic situations. In other words it increases the } \\
\text { range of choices. }\end{array}$ \\
\hline 7 & Readability & $\begin{array}{l}\text { This quality makes an understanding of environment. Environments may be visible in one of two levels } \\
\text { of physically or activity. By strengthen of five elements of Lynch (nodes, edges, landmarks, roads, } \\
\text { districts) readability can be increased. }\end{array}$ \\
\hline 8 & Flexibility & $\begin{array}{l}\text { Powerful combining of places that can be used for different purposes give more range of choices, in } \\
\text { comparison with places that are designed just for one use [11]. The buildings that principle of three } \\
\text { components: depth, accessibility and height are standard at them, functionally are very flexible. }\end{array}$ \\
\hline 9 & Visual proportions & $\begin{array}{l}\text { If the area is clear for people in form and function, have diversity and flexibility, it can be said that visual } \\
\text { proportions is observed. }\end{array}$ \\
\hline 10 & richness & $\begin{array}{l}\text { Richness is a quality which makes varied sensory experiences and enhances pleasure. It includes all the } \\
\text { senses, but because of the impact that sight has in understanding of information, it is somewhat more } \\
\text { important than the others. }\end{array}$ \\
\hline 11 & Personalization & $\begin{array}{l}\text { Making a place that can personalize the huge environment is important to them. This is the only way that } \\
\text { most people find an environment arising from their personal concerns, values, and signs [9]. If an } \\
\text { environment gives a sense of ownership to a person, he/she will have a sense of belonging to } \\
\text { environment. If people use a place regularly and in long term, they will have a sense of belonging to it. }\end{array}$ \\
\hline
\end{tabular}

\section{Provide a Common Standard of Urban Respondents and Vibrancy}

To improve the quality of the environment, taking into design guidelines and essential components offered by theorists is essential. With regard to the aim of this study, to achieve a vibrant urban center in the heart of an area with adequate standards of respondents, common measures are provided which include the goals of both presented arguments and this makes it possible to achieve an overlap. These criteria are presented divided in the below table.

Table 2. Breakdown of respondents and vibrancy components and providing common components.

\begin{tabular}{|c|c|c|c|c|c|c|c|}
\hline \multicolumn{8}{|c|}{ Environmental qualities } \\
\hline \multicolumn{4}{|c|}{ Cyril Paumier in book: "creating a vibrant city center" } & \multicolumn{4}{|c|}{ Bentley and his book Colleagues in book: "responsive environments" } \\
\hline \multirow{2}{*}{$\begin{array}{l}\text { Organizer } \\
\text { structure }\end{array}$} & \multirow{2}{*}{$\begin{array}{l}\text { Concentration and } \\
\text { density or intensity of } \\
\text { land use }\end{array}$} & \multirow{2}{*}{$\begin{array}{l}\text { Land use } \\
\text { variety }\end{array}$} & \multirow{2}{*}{ accessibility } & richness & legibility & variety & Permeability \\
\hline & & & & & Flexibility & $\begin{array}{c}\text { personalizatio } \\
n\end{array}$ \\
\hline \multicolumn{8}{|c|}{ Common and main components of designing a responsive environment and vibrant urban center } \\
\hline \multicolumn{3}{|c|}{ Organizer structure } & Sense of place & $\begin{array}{l}\text { Flexibility } \\
\text { and intensity } \\
\text { of land use }\end{array}$ & $\begin{array}{c}\text { Visual } \\
\text { proportions }\end{array}$ & $\begin{array}{l}\text { Land use } \\
\text { variety }\end{array}$ & Permeability \\
\hline
\end{tabular}

\section{A Prioritization of Common Criteria of Respondent and Vibrant Urban Environment Using Analysis Hierarchy Process AHP}

In this study, after collecting data through questionnaires, urban population experts and field observations, using the analytic hierarchy process (AHP), penetration, land use diversity, visual proportions, flexibility, land use jam, sense of place and organizer structure have been studied as a feature of respondents and vibrancy. Finally, after analyzing the data, a sample solution is presented in table format including policy and strategy. Since the technique is used as a tool for achieving the 
ultimate goal of this research, providing mathematical relationships and how to form decision binary matrices is passed up and all the data was extracted through Expert Choices software. According to the provided theoretical principles and separation and reviews of effective components, common features are offered as six criteria which are introduced in the above table and are the main components of this approach. Based on purposes of this paper, weight of each of them by the binary comparison using the analytic hierarchy process (AHP), the result is shown in table 3 .

Table 3. Weight of criteria

\begin{tabular}{|c|c|c|c|c|c|c|c|}
\hline Design Criteria & Permeability & $\begin{array}{c}\text { Visual } \\
\text { proportions }\end{array}$ & $\begin{array}{c}\text { Sense of } \\
\text { place }\end{array}$ & $\begin{array}{c}\text { Land use } \\
\text { variety }\end{array}$ & $\begin{array}{c}\text { Organizer } \\
\text { structure }\end{array}$ & $\begin{array}{c}\text { flexibility } \\
\text { Ceighting the } \\
\text { criteria }\end{array}$ \\
\hline Permeability & 1 & 2 & 3 & 5 & 6 & 8 & 0.392 \\
\hline Visual proportions & $1 / 2$ & 1 & 2 & 4 & 5 & 7 & 0.262 \\
\hline Sense of place & $1 / 3$ & $1 / 2$ & 1 & 3 & 5 & 6 & 0.182 \\
\hline Land use variety & $1 / 5$ & $1 / 4$ & $1 / 3$ & 1 & 2 & 4 & 0.083 \\
\hline Organizer structure & $1 / 6$ & $1 / 5$ & $1 / 5$ & $1 / 2$ & 1 & 2 & 0.050 \\
\hline flexibility & $1 / 8$ & $1 / 7$ & $1 / 6$ & $1 / 4$ & $1 / 2$ & 1 & 0.031 \\
\hline
\end{tabular}

\section{Case Study}

\subsection{The Historic Core of Qazvin City}

According to historical accounts, historical cornerstone of Qazvin historic city returns to the first shapur in Sassanian period. Historical situation of Qazvin city perches south and core of city, including Green Square, Clergy neighborhood, old Tehran gate, Railway, Sepah, Saadi street and ... . Most of the monuments of Qazvin are located in this area and more it will be analyzed by hierarchical process analysis from the point of respondent and vibrancy. Then by reviewing the effects of criteria in urban open spaces and existing statistic and results, realization of each of these criteria, is provided in studied area and the following factors for the historic fabric of the city of Qazvin (Table 5) regarding to the evaluation period (Table 4) is obtained and the results are shown in table $5 \& 4$ respectively.

Table 4. Evaluation period of realization of criteria

\begin{tabular}{|c|c|}
\hline week & $0-3$ \\
\hline average & $3-6$ \\
\hline good & $6-9$ \\
\hline
\end{tabular}

And finally to measure the quality of components, the values of criteria's weight is multiplied by index (realization ratio) of each of them and their ultimate weight is obtained. To measure the quality of components in the index (the realization) of each beat and the final weight is obtained (Table 5).

It is worth noting that the above comments has been obtained from experts who are involved in the discussion of urban design as well as the authors of this article have been.

Sum of weighted criteria in Table 5 , and also considering expressed qualitative range (Table 6) the vibrancy and dynamism of space is measured.
Table 5. The fulfillment of the criteria and the weights of the historic fabric of the city of Qazvin

\begin{tabular}{|c|c|c|}
\hline $\begin{array}{c}\text { Components of recreating a vibrant } \\
\text { and respondent urban space }\end{array}$ & $\begin{array}{c}\text { Realization of } \\
\text { criteria }\end{array}$ & $\begin{array}{c}\text { Final } \\
\text { weight }\end{array}$ \\
\hline permeability & 5 & 1.96 \\
\hline proportions & 2 & 0.524 \\
\hline Sense of place & 7 & 1.274 \\
\hline variety & 3 & 0.249 \\
\hline Organizer structure & 2 & 0.1 \\
\hline flexibility & 4 & 0.124 \\
\hline The ultimate collection & - & 4.231 \\
\hline
\end{tabular}

Table 6. Range of assessment of environmental vibrancy

\begin{tabular}{|c|c|}
\hline Range of vibrancy of environment & Numerical range \\
\hline Environment is not vibrant & $0-3$ \\
\hline Ability to recreating & $3-6$ \\
\hline Environment is vibrant & $6-9$ \\
\hline
\end{tabular}

In order to assess the importance of each criterion with respect to the binary using analytic hierarchy process (AHP), weight of each criterion is multiplied in the realization of each criteria, in context of the historical city of Qazvin and the conclusion was that with Score 231/4, district has the ability to be recreated and redesigned.

\section{Provision of Appropriate Strategies and Policies for the Development and Promotion of a Vibrant Urban Atmosphere and Responsive}

Following the presented descriptions and reviews, below strategies and policies are provided. (Table 7) 
Table 7. Strategy and policy

\begin{tabular}{|c|c|c|}
\hline Goal & Strategy & Policy \\
\hline \multirow{6}{*}{$\begin{array}{l}\text { Create and promote a } \\
\text { vibrant and responsive } \\
\text { urban spaces }\end{array}$} & Strengthen good permeability & $\begin{array}{l}\text { - Increase the number of accessible routes and entrances } \\
\text { - Avoid allocating space to a particular class } \\
\text { - Organization of public transport services } \\
\text { - Creation of user services such as parking }\end{array}$ \\
\hline & Strengthen the visual proportions & $\begin{array}{l}\text { - Coordinating the construction materials with historical context of district } \\
\text { - Observe the sky and make sense of enclosure } \\
\text { - Avoid any type of buildings construction that corrupt visibility into } \\
\text { historical context } \\
\text { - Connect symptoms to each other by significant walkways } \\
\text { - Attention to details in district and a coordinated range of urban furniture }\end{array}$ \\
\hline & $\begin{array}{l}\text { Maintain and strengthen the identity and } \\
\text { sense of place }\end{array}$ & $\begin{array}{l}\text { - Preserve and enhance significant and evocative areas } \\
\text { - Use appropriate vegetation to stimulate the sense of smell } \\
\text { - The creation of urban open spaces with walking priority } \\
\text { - Especial lighting at night }\end{array}$ \\
\hline & Creating a variety of land uses & $\begin{array}{l}\text { - Predict areas for ceremonies and special activities } \\
\text { - Create a recreational land use such as oral sales } \\
\text { - Create a visual connection between spaces and activities }\end{array}$ \\
\hline & Create an organizing structure & $\begin{array}{l}\text { - The strengthening of network access with respect to hierarchy of road } \\
\text { - Strengthening the coverage of public transport } \\
\text { - The implementation of traffic control rules such as time limits }\end{array}$ \\
\hline & Establish and strengthen the flexibility & $\begin{array}{l}\text { - Activate the edges and make effective use of the mobility and vitality } \\
\text { - Providing animated shelter, shade and places to sit } \\
\text { - Organized and systematic planting of vegetation } \\
\text { - Implant ghosting and autumn plants }\end{array}$ \\
\hline
\end{tabular}

\section{Conclusion}

Structure and designing of urban spaces has a direct impact on people's behavior and choices. The potential for realization of space and environmental quality and the result of the pause in urban areas, underlies seeing and being seen at the lower ground and beyond the interactions and social connections. In fact, the focus is on environmental quality, efficiency and vitality of urban spaces, urban life continuing and strengthening social capital to follow. Classification of criteria and techniques using analytic hierarchy process (AHP) in this case study suggests that the space has ability to reproduce and penetration in the importance of six components: diversity of land uses, visual proportions, flexibility and compactness of land use, sense of place and organized structure reflects the vibrant urban space in order to achieve a responsive environment considered in the context of the historic fabric of the city of Qazvin and has been carefully analyzed. Besides, this range of tourist attractions, cultural and social needs of residents can be a great feature and unfortunately this feature currently lacking. In fact, people only come to visit the historic environment as a single element, and after visiting this space they leave the space and do not remain in the environment for recreation. Finally, compliance with standards, policies and strategies for strengthening and recreating the components expressed in table (Table 7) has been proposed.

\section{REFERENCES}

[1] M. Lopes, A. Camanho, Public Green Space Use and Consequences on Urban Vitality: An Assessment of European Cities, Springer Science Business Media journal, 2012

[2] S. Rastbin et al. the relation between environmental quality and sustainability of urban life in the public arena, Garden Bulletin No. 21: 35-46, 2012.

[3] M. Carmona, et al. public places urban spaces, translation: Fariba gharai, readings and others, Tehran University of Art, 2009.

[4] R. Cowan, The Dictionary of Urbanism, Streetwise press. 2005.

[5] Ch. Landry, Urban Vitality: A New Source of Urban Competitiveness, Prince ClausFund Journal, ARCHIS issue 'Urban Vitality / Urban Heroes 2000.

[6] ORUÇ, D. GİRITLIOĞLU, C. The evaluation of urban quality and vitality of the Istanbul historical peninsula-Eminönüdistric, ITU Journal, VOL: 5 NO: 1, 97-117, 2008.

[7] M. Khastou, N. SaeediRezvani, Factors affecting the vitality of urban spaces creating a lively urban environment with emphasis on the pedestrian shopping center, the Journal of Identity, 6: 63-74, 2010.

[8] I. Wong, Creating a vibrant downtown, The Monieson Center Journal, 2009.

[9] http://www.waterloo.ca/en/government/economicvitality.asp

[10] Economic Vitality Strategy 2010 Update, Community Development Department 1950 Parkside Drive, MS/01B Concord, CA 94519-2578

[11] I. Bentley, et al. responsive environments, translations: Mustafa Behzadfar, Tehran, Iran University of Science and Technology, 2003. 